\title{
THE PROBLEMS OF THE KHI ON ARTICLE 7 ABOUT THE MARRIAGE ISBATIN A RELIGIOUS COURT
}

\author{
Muhammad Sabir \\ Fakultas Syariah dan Ilmu Hukum Islam \\ Institut Agama Islam Negeri (IAIN) Parepare \\ muhammadsabir@iainpare.ac.id \\ Aris \\ Institut Agama Islam Negeri (IAIN) Parepare \\ aris@iainpare.ac.id \\ Iin Mutmainnah \\ Institut Agama Islam Negeri (IAIN) Parepare \\ iinmutmainnah@stainparepare.ac.id
}

\begin{abstract}
Abstrak: Sebelum melangsungkan perklawinan, terdapat beberapa rukun dan syarat yang mesti dipenuhi yang telah ditetapkan oleh undang-undang. Salah satunya adalah pencatatan perkawinan. Syarat tersebut bertujuan untuk memberikan kepastian dan pengakuan hukum bahwa sebuah perkawinan pernah terjadi. Akan tetapi pada kenyataannya masih banyak perkawinan tidak dicatat atau didaftarkan pada pegawai pencatat perkawinan yang berwenang. Pengadilan Agama selaku pelaksanan kekuasaan kehakiman dalam menangani masalah perkawinan dibutuhkan kejelian dalam menyelesaikan permasalahan tersebut. Penelitian ini bertujuan untuk mengenalisis pelaksanaan pasal 7 dalam KHI di Pengadilan agama tentang isbat nikah daln melihat penyebab sehingga terjadi isbat nikah. Dengan menggunakan pendekatan sosiologis dan yuridis, hasil dari penelitian ini bahwa masih banyak terjadi perkawinan bawah tangan yang dijumpai di pengadilan agama. Hal demikian terjadi karena berbagai faktor. Olehnya itu dibutuhkan kejelian pengadilan agama dalam menagani perkara tersebut dan dibutuhkan kehadiran Negara agar menyelesaikan sehingga praktek perkawinan tersebut tidak terjadi lagi.
\end{abstract}

Kata kunci: Perkawinan, isbat nikah, Pengadilan Agama

Abstract: Before having a marriage, several pillars and conditions that must be fulfilled which have been regulated by law. One of them is marriage registration. This requirement is to provide legal certainty and recognition that a marriage has occurred. However, in reality, there are still many marriages that are not recorded or registered to 
the authorized marriage registrar. The Religious Court as the implementor of judicial power in handling marital problems requires carefulness to resolve this problem. This aims to analyze the Article 7 implementation in the KHI in the religious court regarding the isbat of marriage and to see the causes that lead to marriage isbat. By using a sociological and juridical approach, the results of this study show that there were still many underhand marriages in religious courts. This marriage happened because of various factors. Therefore, religious courts need to be careful in handling these cases, and in the presence, the help of the State is needed to resolve it so that this practice of marriage does not occur.

Keywords: Marriage, isbat, religious courts.

\section{INTRODUCTION}

Islamic law is a textual translation and becomes an Indonesian term. Hasbi ash-shiddieqi said Islamic law is a law applied to society that has been adapted to the situation, conditions, and social needs. ${ }^{1}$

Islamic law is also explained as a rule or principle used by the Islamic community. It can control, whether in the form of the al-Quran, hadith, sahabah's thoughts, or even opinions that develop in Muslim's life. ${ }^{2}$ Islamic law and syariah are similar. They are the norms or rules of Allah that have been revealed as contained in the al-Quran

${ }^{1}$ Hasbi Ash-Shiddiqiey, Falsafah Hukum Islam cet.IV (Jakarta: Bulan Bintang, 1993), 44.

${ }^{2}$ Abdul Aziz Dahlan At Al., Ensiklopedia Hukum Islam Cet.I (Jakarta: Ichtiar Baru Van Houve, 1996), 575. and hadith. As for fiqh, it means legal rules that the mujtahid obtained from the Al-Quran and Hadith from the process of reasoning. However, the assumption that is spread among people is that Islamic law is the same as fiqh. So Islamic law is closer in the meaning to fiqh than shari'ah.

Furthermore, in the history of Islamic law, it has come a long way to gain recognition and position in the legal system in Indonesia, including the compilation of Islamic law. The next discussion is about the compilation of Islamic law or known as KHI (Kompilasi Hukum Islam). ${ }^{3}$ In a legal context, the regulation and compilation have a little difference, which means that the

${ }^{3}$ Compilation of Islamic Law in the next discussion will be abbreviated as KHI. 
accounting of a certain law contains certain rules, opinions, and legal rules. ${ }^{4}$

The compilation of Islamic law is a collection of rules or Islamic civil laws that contain three legal books, namely marriage, inheritance, and representation on the juridical basis of Presidential Instruction number 1 of 1991. The validation of Islamic law contained in the KHI is well received by the Indonesian people. ${ }^{5}$ The compilation of Islamic Law in Indonesia is the result of processing, development, and compilation in one legal set that goes through the process of summarizing various existing books that have been issued by fiqh scholars and used as references in the Religious Courts. Apart from that, if we connect the word compilation with Indonesian Islamic law, it means that it is fiqh in legislation and there are chapters, articles, and verses in it. ${ }^{6}$

\footnotetext{
${ }^{4}$ Abdurahman, Kompilasi Hukum Islam, Jakarta: Akademika Pustaka Presisindo, 1992), 12.

${ }^{5}$ Alimuddin, Kompilasi Hukum Islam Sebagai Hukum Terapan Bagi Hakim Pengadilan Agama (Makassar: Alauddin University Press, 2011), 6.

${ }^{6}$ Sanusi, A. Pelaksanaan Isbat Nikah di Pengadilan Agama Pandeglang. AHKAM: Jurnal Ilmu Syariah, 16(1). (2016): 133.
}

In this article, the authors discuss Article number 7 regarding the marriage isbat on KHI because it appears in the implementation of marriage, and people still tend to be confused. There was a conflict between registering their marriage or not. This conflict appeared because the people considered that their marriage was still valid if the terms and conditions had been fulfilled. The religious court as the enforcer of law in resolving problems surrounding marriage is required to be more careful in resolving the problems, especially regarding cases of marriage isbat.

\section{METHOD}

This article uses a sociological and normative approach. The authors describe the implementation of marriage isbat in religious courts by linking Article 7 of the KHI. Therefore, in this study, the authors discuss the implementation of KHI Article 7 in the religious court then the causes or problems of unregistered marriage, and the solutions offered. 


\section{RESULTS AND DISCUSSION}

\section{Implementation of KHI in Article}

7 concerning marriage isbat at the Religious Court

Before presenting the implementation of KHI in Article 7 in the Religious Court, the authors discuss the concept of marriage. Marriage in jurisprudence (fiqh) is defined as an agreement, (contract) that contains the meaning of the ability to have a husband and wife relationship and use the lafaz of marriage or tazwij. The Fuqaha and the four mazhab have agreed that marriage is a contract or agreement that makes sexual relations legal. And many other definitions of marriage have existed. However, according to the authors, if marriage is only interpreted as legalizing sexual relations ${ }^{8}$, then this meaning is too narrow. Marriage should not only legalize the relationship, but there are rights and obligations as a legal aspect.

In the compilation of Islamic law (KHI), chapter II, the basics of marriage, Article 2 states said:

${ }^{7}$ Beni Ahmad Saebani dan Syamsul Falah, Hukum Perdata Islam di Indonesia (Bandung: CV Pustaka Setia, 2011), 32.

8Ibid., 32.
Marriage according to Islamic law is marriage, which is a very strong contract or mitsaqan ghalidzan to obey Allah and carry it out is worship.

The word mitsaqan galidzan in the article above means a strong bond or a strong bond that binds itself between a man and a woman to have a relationship that was originally haram to become lawful and marriage is an order of Allah and in that marriage, it contains cause and effect.

According to the Marriage Law Number 1 of 1974 in Article 1 said:

Marriage is a physical and mental bond between a man and a woman as husband and wife to form a happy and eternal family (household) based on the One Godhead. $^{10}$

'Undang-Undang RI Nomor 1 Tahun 1974 tentang Perkawinan dan Kompilasi Hukum Islam, Dilengkapi : PP RI Nomor 9 Tahun 1974, PP RI Nomor 10 Tahun 1983, PP RI Nomor 45 Tahun 1990, Peraturan menteri Agama RI Nomor 11 Tahun 2007, Peraturan Menteri Pertahanan Keamanan/Panglima Angkatan Bersenjata Nomor:Kep/01/1980, Petunjuk Teknis No. Pol.: JUKNIS/01/III/1981, Peraturan Kepala Kepolisian Negara RI Nomor 9 Tahun 2010, UU RI Nomor 41 Tahun 2004, UU RI Nomor 12 Tahun 2006, UU RI Nomor 23 Tahun 2001, PP RI Nomor 42 Tahun 2006, Keputusan Presiden RI Nomor 8 Tahun 2001, UU RI Nomor Tahun 2004 ( Surabaya : Sinarsindo Utama, 2015 ), 341. ${ }^{10}$ Ibid., 3. 
In addition to defining marriage, it also mentions the benefits that a marriage wants to achieve in building or forming a happy and eternal household based on divine values. Apart from that, Article 3 of the KHI mentions the purpose of marriage, is:

Marriage aims to create a sakinah, mawaddah, and rahma household life. $^{11}$

Every society that has built a household certainly dreams of an ideal, peaceful, and eternal household, but in the process of living, there are various kinds of obstacles and life problems. So that, the dreams do not come true. It shows the importance of society's understanding of marriage law and matters related to it. This understanding includes preparation for candidates who want to build a household both internally and externally. ${ }^{12}$

\section{${ }^{11}$ Ibid., 341.}

${ }^{12}$ The internal understanding that the authors means here is the understanding of candidates who want to foster households to prepare themselves the physically and psychologically, materially and non-materially, that fostering a household is not only related to biological fulfillment but is related to all aspects of life and in it contains a very large responsibility in fulfilling rights and obligations. While external understanding, namely those
Islamic law and marriage law regulations that apply in Indonesia have set conditions that must be fulfilled. The pillars are the qabul, the bride and groom, the guardian, two witnesses, and the conditions that must be fulfilled in a marriage.

On the other hand, the pillars and conditions of marriage are also regulated in the Compilation of Islamic Law from Article 14 to Article 29. In the authors' opinion, based on the explanation of the scholars and the above regulations relating to the pillars and conditions of marriage, it is a procedure that must be understood and fulfilled if someone wants to marry. If one of them is not carried out, the marriage will be invalid or canceled.

For a country, especially Indonesia, which is based on the law, it is mandatory to have a Marriage Law as a rule that provides legal certainty for its citizens. This is because the existence of

related to marriage procedures, attention, and understanding of marriage procedures is also very necessary and important so that there is no violation of the marriage law, which causes the marriage to be invalid, both as regulated in legislation and religion. Such as principles and marriage requirements, restrictions in marriage, and others. 
marriage law is marked by the existence and enforcement of Indonesian law as one of the national legal systems. ${ }^{13}$ Marriage law which is regulated in the Republic of Indonesia Law Number 1 of 1974 and the Compilation of Islamic Laws has a national standard, which is also from the Al-Qur'an and Hadith. Therefore, all citizens without exception, especially Muslims, must follow and obey these rules. ${ }^{14}$

The most fundamental thing from marriage law is related to the legality of marriage because it has a very close relationship with the consequences of the marriage law, such as the effect on the relationship between husband and wife, offspring (children), property, and others. ${ }^{15}$ The criteria for the validity of marriage have been formulated in Law Number 1 of 1974 as stated in Article 2, said:

${ }^{13}$ Abdul Manan, Reformasi Hukum Islam di Indonesia (Jakarta: PT Raja Grafindo, 2006), 96.

${ }^{14}$ Muchsin, Agus, and Muhammad Sabir. "Legalitas Perkawinan yang Tidak Tercatat pada Masyarakat Pinrang (Analisis Perma Nomor 1 Tabun 2015 tentang Pelayanan Terpadu Pencatatan Nikah)." DIKTUM: Jurnal Syariah dan Hukum 17.1 (2019): 33

${ }^{15} \mathrm{M}$. Anshary MK, Hukum Perkawinan di Indonesia: Masalah-Masalah Kruisal (Yogyakarta: Pustaka Pelajar, 2015), 12.
(1) Marriage is legal if it is carried out according to the law of each religion and belief.

(2) Every marriage is recorded according to the prevailing laws and regulations.

The validity of a marriage is also regulated in the Compilation of Islamic Law in Article 4 as follows:

Marriage is legal if it is carried out according to Islamic law under Article 2 verse (1) of Law Number 1 of 1974 about marriage.

Marriage registration at the authorized marriage registration institution is evidence to prove that a marriage has happened. In the process of proof in court, documents issued by the state are strong and authentic evidence as a form of legal certainty. ${ }^{16}$ Conversely, unregistered marriages ${ }^{17}$ do not have legal consequences and do not have legal recognition. The Marriage Law and KHI regulate the registration of marriage, aiming to maintain the sanctity and dignity of marriage, especially for women.

\footnotetext{
${ }^{16}$ Muhammad Faisal Hamdani, Nikah Mut'ah: Analisis Perbandingan Hukum antara Sunni dan Syiah (Jakarta: Gaya Media Pratama), 132.

17Today, unregister marriages are commonly known as underhand marriages or sirri marriages
} 
History shows that the Prophet Muhammad SAW neither recorded a marriage nor ordered a friend to do it. The command to record is only found in the Al-Quran related to the contract in muamalah or the agreement as said by Allah SWT in Q.S al-Baqarah / 2: 282.

At a glance, the above verse has no connection with marriage registration because the verse talks about the muamalah agreement in terms of debt and credit. However, if we trace it further, it will be found that it is related to the registration of marriages. Marriage in a broad sense is muamalah. The word mitsaqan gholidzan in KHI means a strong contract or agreement, so that recording in muamalah is the same as marriage registration, only the strength of the bond is stronger than other muamalah. Therefore, marriage registration is necessary as a form of legal certainty.

The problem now is about unregistered marriages. Isbat means stipulation or determination. Doing isbat means determining the truth of something. If the word isbat is combined with nikah (marriage), it means marriage determination. ${ }^{18}$

According to the authors, isbat nikah (marriage isbat) is a solution for unregistered or illegitimate marriage. An illegitimate marriage does not get a marriage certificate (marriage book). The benefits of this marriage ceremony are very large, as the authors said earlier, to get a marriage book as proof that the marriage has ever occurred, get legal protection, legal recognition from both the state and society, especially it is beneficial for wives and children.

It is a truth that marriage isbat is the solution taken to obtain the validity of a marriage that has occurred if the marriage is not registered at the authorized registration institution. The implementation of a marriage is an

${ }^{18}$ Marriage isbat according to the decision of the chairman of the Supreme Court of the Republic of Indonesia Number KMA / 032 / SK / 2006 regarding guidelines for the implementation of court duties and administration that the marriage isbat is the legalization of a marriage that has been carried out according to Islamic law, but is not recorded by the KUA or the authorized PPN. The technical manual for the administration of religious courts in 2010, explains that the isbat marriage is a statement regarding the validity of a marriage that is carried out based on religion and unrecorded by the authorized PPN. 
important event that has happened, as is the case with other events such as births, deaths, and other events that have a decree. ${ }^{19}$ Marriage isbat is not found in classical fiqh books but it is a good breakthrough in problems in marriage law. ${ }^{20}$ The basis for determining marriage or marriage ritual can be found in KHI, as follows:

\section{Article 7}

(1) Marriage can only be proven by a Marriage Certificate made by a marriage registrar employee

(2) In the event that the marriage cannot be proven by a marriage certificate, the marriage certificate may be submitted to the Religious Court.

(3) Marriage rituals that can be submitted at the Religious Court are limited to matters relating to:

a. There is a marriage in the context of divorce settlement

b. Loss of marriage certificate

c. There are doubts about whether or not one of the

${ }^{19}$ Sururie, R. W. Polemik Di Seputar Hukum Isbat Nikah Dalam Sistem Hukum Perkawinan Indonesia. Al-Manahij: Jurnal Kajian Hukum Islam, 11(2), (2017): 235.

${ }^{20}$ Nurlaelawati, E. Pernikahan Tanpa Pencatatan: Isbat Nikah Sebuah Solusi?. Mus ,wa Jurnal Studi Gender dan Islam, 12(2), (2013): 264. conditions of marriage is valid

d. The existence of marriages that occurred before the enactment of law number 1 of 1974 and

e. Marriages conducted by those who do not have a marriage barrier according to Law No.1 of $1974{ }^{21}$

Beside the KHI, the marriage law (Law Number 1 of 1974) is also the basis of the judge's foundation in settling marriage cases, because isbat is a part of marriage, of course also becomes the authority of the Religious Court. The bases are as follows:

\section{Article 2}

(1) Marriage is legal if it is carried out according to the law of each religion and belief.

(2) Every marriage is recorded according to the prevailing laws and regulations.

\section{Article 64}

For marriage and everything related to marriage that occurred before this law came into effect which was carried out according to the old regulations, is legal.

Religious Court and as well as other courts have the main duties of each, so

${ }^{21}$ Articel 7 KHI 
it mandatory for judges of the court to receive, examine, judge and resolve cases. In the case of marriage, this becomes one of the main tasks or what is called the absolute authority of the Religious Courts to resolve it, including cases of marriage isbat which is part of the marriage itself.

The conclusions that can be drawn from the contents of the article and the results of the authors' interviews are from the foundation of the Religious Courts in handling marriage isbat matters as stipulated in the Republic of Indonesia Law Number 1 of 1974 concerning Marriage and Presidential Instruction Number 1 of 1991 concerning Compilation of Islamic Laws are the draft of the Religious Courts Law in resolving marriage matters. This authority can be seen in the religious court law. ${ }^{22}$

${ }^{22}$ The law Number 50 of 2009 years on amendments to law Number 3 of 2006 yeras on amendments to law Number 7 of 1989 Yeras. In article 49: The Religious Court has the duty and authority to examine, decide and resolve cases at the first level between people muslim in the field of a. marriage; b. inheritance; c. wasiat; d. hiba; e. waqf; f. zakat; g. infaq; h. shadaqah and; i. Islamic economics.
It is imperative for judges to accept and settle cases that are faced with him as long as the case is in his jurisdiction, both absolute and relative authority. And the prohibition for judges to reject it on the grounds that the case is baseless or there is no law regulating it, therefore it is the obligation for the judge to explore and carry out ijtihad with all his ability to find law by looking at the values that live and develop in society. ${ }^{23}$ The requirement of ijtihad for judges is based on the principle that states ius curia novit. ${ }^{24}$ This is under the history which states that when the Prophet Muhammad sent Muaz 'bin Jabal to Yemen to solve problems there. In this dialogue, he will use his reason in the sense of doing ijtihad if the problems he is facing do not find the law in the al-Quran or the hadith.

The problem with the determination of this marriage (isbat nikah) is related to

\footnotetext{
23Zaidah, Yusna. "Isbat Nikah dalam Perspektif Kompilasi Hukum Islam Hubungannya dengan Kewenangan Peradilan Agama." Syariah: Jurnal Hukum dan Pemikiran 13.1 (2014): 3.

${ }^{24}$ This principle explains that the judges are considered to know the law, there is no reason for him that the case he is handling has no law that regulates it, therefore it is his obligation to perform ijtihad.
} 
the marriage that occurred before the marriage law came into effect, as contained in KHI Article 7 verse 3 (d). However, the reality is that marriage cases submitted to court are also marriages that have been carried out after the enactment of this Law. Therefore it takes accuracy and carefulness of the judge and looks for reasons to accept isbat case that is petitioned to him. ${ }^{25}$

The submission of a marriage request to the Religious Court did not only occur before the enactment of law number 1 of 1974 concerning marriage but also marriages that occurred after the law came into effect, we as a panel of judges certainly have considerations to accept and reject the case. Whether the marriage occurred before or after the marriage law came into effect, we will accept it as long as the marriage fulfills the pillars and conditions, but if it does not fulfill the elements then it will be rejected. And what needs to be

\footnotetext{
${ }^{25}$ Sulistiani, Siska Lis. "Analisis Yuridis Aturan Isbat Nikah Dalam Mengatasi Permasalahan Perkawinan Sirri Di Indonesia." Tabkim (Jurnal Peradaban dan Hukum Islam) 1.2 (2018): 42.
}

underlined here is that granting the marriage request does not mean ratifying but only stipulates that his marriage has occurred so that he obtains a marriage book as a means of proof. ${ }^{26}$

So can be understood that the Religious Courts as law enforcers that have been mandated by the state to examine, adjudicate, and examine isbat cases, especially those related to marriage rituals, whether the marriage occurs before and after the marriage law comes into effect, it will be accepted as long as the marriage fulfills the pillars and conditions, vice versa if In the trial process, it is proven that it does not fulfill these elements, so the application will be rejected.

Based on the results of the authors' interviews with Religious Court judges, all said that the KHI in Article 7 is very well implemented and helps people who have problems with marriage cases, especially those related to marriage isbat, as well as judges, especially the Religious Courts, have implemented what has

\footnotetext{
${ }^{26}$ Muhammad Fitrah, The judges of religious courts Sungguminasa, the interview Gowa 14 November 2019.
} 
been mandated by the Law. It is implemented properly by looking at the cases of isbat requests that judges received. This indicates that there is public awareness that the recorded marriage is very important to them. In addition, it can be said that $\mathrm{KHI}$ as one of the guidelines for judges is almost $100 \%$ a reference for Religious Court judges in examining and resolving cases under their authority.

Marriages should be recorded, but there are still some parts of the community who do not register their marriages, whether those marriages occurred before the enactment of Law Number 1 of 1974 about Marriage or after the Law came into effect. This unregistered marriage certainly does not have a marriage book, while the marriage book is very important in taking care of administrative arrangements such as managing KTP, KK, childbirth certificates, processing passports, administering civil servants, and others. So with this awareness, the community submits a marriage request in court to obtain marriage legalization so that the KUA can issue a marriage book so that the existence of a marriage book means that they can take care of other correspondence that the community needs. In addition, there is a mandate from the law, especially KHI to complete the marriage isbat, therefor the marriage $i s b a t$ is very useful and very helpful for the community. ${ }^{27}$

The awareness of the public who have performed marriage isbat by submitting a marriage request, in the Religious Court as the judge said in the authors' interview above. The authors attach some data on marriage ceremonies received at the Religious Court which is the location of this research, which are as follows:

The isbat cases received by several Religious Courts in South Sulawesi show that there are still many requests for marriage isbat that have been submitted to the Religious Courts. And the obligation for the court to accept it is because it is one of the jurisdictions of the Religious Court regarding marriage. As well as a prohibition to reject it because that there is no law governing it. These are cases related to the request

${ }^{27}$ Ibid 
for marriage isbat because the marriage was not recorded, whether it was marriage before the Marriage Law enacted or marriage that occurred after the marriage law was enacted. Examples of cases are as follows:

Case Number 436 / pdt.p / 2019 / PA Sgm is a case of requesting marriage isbat. The applicant had submitted his application on October 15, 2019. Because the applicant married on February $4^{\text {th }}, 2018$, according to Islamic law, and had fulfilled the pillars of marriage and there were no obstacles between the two of them to carry out the marriage, it was just not registered with the local KUA. Their marriage had a child so that during the marriage between the applicant and the person requested by him, he had never had a marriage book. Therefore, the applicant submitted a marriage isbat or legalization of marriage to obtain his marriage certificate. During the trial process, the case had been carried out properly. Judges' legal considerations were to avoid undesirable things and to obtain certainty and order and other interests justified by law, that the marriage between the applicant and the one petitioned for him was carried out according to harmonious Islamic law and the conditions had been fulfilled based on the facts in the trial. Based on these considerations, the panel of judges was that the pillars and conditions of marriage were fulfilled under Islamic law and Article 2 paragraph (1) of the marriage law in conjunction with Article 14 KHI vide Article 7 verse 3 letters d and e. As the result, the judges concluded that the applicant and the respondent had sufficient grounds that it should be granted by declaring their marriage legal. Then the panel of judges granted the applicant's petition and the judge determined that the marriage was legal, which took place on February $4^{\text {th }}$, 2018. In the opinion of the author, the submission of marriage isbat above is an application for marriage that is not recorded even though a marriage law has been established which stipulates that marriage is recorded at the local KUA. However, the KHI provides an opportunity for the marriage to propose the legalization of marriage that will take place after the enactment of the law. 
Meanwhile in case number 17 / pdt.G / 2019 / PA Tkl is a case of requesting marriage isbat because the marriage between the applicant and the one being petitioned for occurred before Law Number 1 of 1974 applied as the reason for the applicant's case filing marriage isbat on January $10^{\text {th }}$, 2019, at the Takalar Religious Court. Between the applicant and those who petitioned for him had married in 1966, between the two there was no obstacle for him to get married (no blood relationship, sister or brother relationship). And had fulfilled the pillars and requirements to get married. Whereas the applicant's husband during his lifetime was a civil servant. During the marriage, the applicant did not receive a marriage certificate from a marriage registrar. Therefore, the applicant's intention to apply for a marriage certificate was to take care of the funeral money and the transfer of the pension to the applicant's widow pension and others that was the right of the applicant at the PT. TASPEN Makassar Branch. Based on the ongoing trial process, the statements of the applicants and the testimonies of the proposed witnesses. Judges legal considerations that the marriage has fulfilled the terms and conditions and there was no prohibition to marry between the two based on evidence and facts in court and the applicant's petition had been proven and reasoned and the purpose of the applicant filing marriage legalization was to serve as a legal reason for completing money management grief and the transfer of the applicant's widow pension and other rights of the applicant at the Makassar branch of PT Taspen. Then the judge granted the petitioner and legalized the marriage between the applicant, and the one being petitioned for it.

\section{The Problems}

\section{Unregistered Marriage}

As a material for reflection, there are still many people who carry out marriage events in terms of only the validity of their religion, without taking into account the mandate of Article 2 verse (2) of the Marriage Law regarding marriage registration. This expression is not mere talk without evidence, because 
we can find it both from the media and in the environment around us, even the research data that the authors have previously described as evidence that illegal marriages (unregistered marriages) are still widely requested in the Religious Courts. Even though the Government as the holder of power has made efforts and socialized the importance of marriage registration, there are still many unregistered licenses. The increasing number of unregistered marriage practices and therefore not obtaining a marriage book is based on several reasons:

The number of marriage cases in the Religious Courts apart from marriages that occur before the marriage law applies also marriages after the enactment of the marriage law, but their marriages are not registered with the marriage registrar employee from the KUA, the reason they do not register their marriage is because of intermarriage and public understanding that their marriage still valid even though it is not registered at the KUA, negligence on the part of the bride and the KUA, the marriage does not meet the requirements of the marriage law, which provides a limit of 16 years for women and 19 years for men and now changes to 19 years each, polygamy which does not get the permission of the first wife and the court's permission, village marriages that are married by their spiritual teachers even marriages that occur overseas.

The reasons for the occurrence of marriage were not recorded as the results of the interview above were found in all Religious Courts at the author's research location, the reasons for these facts are described as follows:

a. There is negligence on the part of the bride and groom in carrying out a marriage that is not according to the applicable procedure. The negligence that is meant is blind or does not understand the applicable law. Because they are not educated or maybe they just don't want to know.

b. Have been married before the marriage registration rules in the Republic of Indonesia Law Number 1 of 1974. 
c. Illegal polygamy because the marriage does not fulfill what is stipulated by the marriage law, namely the permission of the first wife and permission from the Religious Court. In Islamic teachings, there is no prohibition against polygamy. Islam clarifies the number and limits for practicing polygamy with certain conditions. Matters related to polygamy are contained in Articles 3, 4 and 5 of Law Number 1 Year 1974.

d. The concept that is embedded in society considers that guardianship is only worthy of being given to their teachers or scholars because it is considered sacred (even this understanding has become extreme). The transition in marriage by the scholars of the Syafi'iyah is very strictly regulated, as in the Qulyubi khasiyah book it is described that:

Let a woman not marry herself, either with the permission of her guardian or without the permission of her guardian. Marriage in this type is very careful so that the presence of a guardian in one assembly when performing aqad (consent and qabul) is a necessity. ${ }^{28}$

e. Marriage does not meet the requirements of the law such as marriage underage. ${ }^{29}$ This practice of marriage is strictly forbidden, because of the huge impact it has on the marriage. The reason is quite plausible because marriage at age is easy to think that their minds are not yet mature, are not ready to carry out the reproductive process, and sometimes emotional control tends to be unstable.

This marriage model is a dilemma because it is not regulated

${ }^{28}$ Al-Qulyubi dan Umairah, Khasiyah Qulyubi wal Umairah juz 4, (Beirut:Dar al-Kutub, 2001), h. 452. See in Sulaiman Jamal, Khasiyah Jamal 'alal Minhaj juz 3, (Beirut: Dar al-Fikr, 2002), 139; Sulaiman al-Bujairimi, Khasiyah Bujairimi 'ala al Minhaj juz, 4, (Beirut: Dar al-Fikr, 2002), 244.

${ }^{29}$ The underage marriage or usually called as child marriage, early marriage is a marriage that is carried out because it does not fillful the requirements of the rules in the marriage law No.1 of 1974 article 7 paragraph (1) marriage is only permitted if the male has reached the age of 19 twelve) years and the woman has reached the age of 16 (sixteen) years. Currently, it has been replaced by men and women for at least 19 years. See the latest marriage law, Law Number 16 of 2019. 
in the Marriage Law, it only provides a minimum limit of ideal age, namely after the age of 21 , for each bride. However, the Marriage Law allows men under 19 years of age and women under 16 years of age provided that they receive marriage dispensation from the Religious Court. Meanwhile in the fiqh does not provide an age limit but only with the requirements of baligh (mature), so from here some people marry even though the age requirements are not fulfilled, so marriage registration is not carried out.

f. Marriages that have occurred overseas where they are looking for work. Generally, they leave because of economic pressure, which is increasing every day. In addition to the economic needs of people overseas, fulfillment sexual is also needed. Of course, so that these sexual needs are not contradictory, they are married, it's just not recorded even though the pillars and conditions marriage is fulfilled. Conducted a marriage without being registered at an overseas place because of ignorance of the procedure or a rather complicated procedure. Marriage like this is risky for husband and wife and their children, after several years of being overseas, it does not preclude that they will return to their hometowns and of course move domicile. The change of domicile is of course obliged to carry out an orderly administration of entering family data at the population and civil registration services. Thus, when a family should attach a certificate in the form of a marriage certificate and a child's birth certificate, this involves the Office of Religious Affairs (KUA) and the Religious Court (PA).

g. Elopement (silariang). Kawin silariang is a marriage that is carried out by both parties (male and female) based on of mutual love. There are several reasons for the practice of this marriage, namely the rejection of the woman's family when applying for reasons of differences in social strata, high panai (dowry), and the 
possibility that her idol woman has

been proposed by other youths.

In a marriage, some rights and obligations must be carried out and there are also marriage agreements. Because marriage is a strong contract or agreement between a man and a woman as husband and wife. The rights and obligations inherent in them, the State, in this case, has formulated them into the Marriage Law No.1 of 1974. The formulation of these rights and obligations is in line with what has been mandated by the Al-Quran and Hadith (Islamic teaching values). Therefore, awareness is needed for the Muslim community in Indonesia that the issue of marriage registration is very important. ${ }^{30}$ So, by carrying out a marriage under the demands of the laws in force in Indonesia, it means that he

\footnotetext{
${ }^{30}$ Marriage registration is very important because it is direct religious teaching as an order of Allah SW'T in Q.S al-Baqarah / 2: 282 which is related to the command to write or record muamalah activities. Apart from that, if you look at the history of Islamic law in Indonesia, history has recorded that the Islamic community has fought for Islamic law to become one of the laws in the legal system in Indonesia so that it has binding power and forces it to be obeyed and carried out by all Muslim communities.
}

has carried out what Allah and His Messenger have ordered.

Marriages that occur unregistered (unregistered marriages) with various factors that the authors have previously presented are a problem in marriage law. Help or the presence of the state is needed as a solution to the problems faced by the community because there will be quite serious impacts if there is no treatment. The formation of rules in the Marriage Law concerning the obligation of every citizen to carry out marriage so that if it is registered and recorded at the authorized marriage registration agency, in this case, the KUA and submission of a marriage request to the Religious Court as a solution to unregistered marriage.

\section{CONCLUSION}

This research describes the implementation of marriage isbat in religious court and the problems in marriage isbat. It appears that there are still many marriage isbat in the religious courts. Marriage isbat happened because the marriage that has been carried out does not meet the requirements 
stipulated by law. This requirement is the obligation to register a marriage at an authorized marriage registrar. Unregistered marriages result in the marriage not getting legal recognition and force of law. As well as detrimental to wife and children.

the factors of the occurrence of marriage isbat are: There is negligence on the part of the bride and groom in carrying out a marriage that is not according to the applicable procedure, Have been married before the marriage registration rules in the Republic of Indonesia Law Number 1 of 1974, Illegal polygamy, The concept that is embedded in society considers that guardianship is only worthy of being given to their teachers or scholars because it is considered sacred, Marriage does not meet the requirements of the law, Marriages that have occurred overseas where they are looking for work, and Elopement (silariang).

Therefore it requires special attention and handling by the government in handling unrecorded marriage practices, the authors agree that marriage is a solution, but the need for detection and emphasis so that people do not violate the provisions of marriage.

\section{REFERENCES}

Abdurahman. Kompilasi Hukum Islam. Jakarta: Akademika Pustaka Presisindo, 1992.

Ahmad, Beni. Saebani. Syamsul Falah, Hukum Perdata Islam di Indonesia. Bandung: CV Pustaka Setia, 2011.

Alimuddin. Kompilasi Hukum Islam Sebagai Hukum Terapan Bagi Hakim Pengadilan Agama. Makassar: Alauddin University Press, 2011.

Anshary, Muhammad MK. Hukum Perkawinan di Indonesia: MasalahMasalah Kruisal . Yogyakarta: Pustaka Pelajar, 2015.

Aziz Dahlan, Abdul. At Al., Ensiklopedia Hukum Islam. Cet.I; Jakarta: Ichtiar Baru Van Houve, 1996.

Bahrum, Mukhtaruddin. "Legalisasi Nikah Sirri Melalui Isbat Nikah Menurut Kompilasi Hukum Islam." Jurnal Diskursus Islam 1.2 (2013).

Faisal Hamdani, Muhammad. Nikah Mut'ab: Analisis Perbandingan 
Hukum antara Sunni dan Syiah. Jakarta: Gaya Media Pratama.

Manan, Abdul. Reformasi Hukum Islam di Indonesia. Jakarta: PT Raja Grafindo, 2006.

Muchsin, Agus, and Muhammad Sabir. "Legalitas Perkawinan yang Tidak. Tercatat pada Masyarakat Pinrang (Analisis Perma Nomor 1 Tabun 2015 tentang Pelayanan Terpadu Pencatatan Nikah)." DIKTUM: Jurnal Syariah dan Hukum 17.1 (2019)

Nurlaelawati, E. Pernikahan Tanpa Pencatatan: Isbat Nikah Sebuah Solusi?. Mus „wa Jurnal Studi Gender dan Islam, 12(2), (2013).

Al-Qulyubi. Umairah, Khasiyah Qulyubi wal Umairah juz 4. Beirut:Dar alKutub, 2001.

Sanusi, A. Pelaksanaan Isbat Nikah di Pengadilan Agama Pandeglang. AHKAM: Jurnal Ilmu Syariah, 16(1). (2016).

Sulistiani, Siska Lis. "Analisis Yuridis Aturan Isbat Nikah Dalam Mengatasi Permasalahan Perkawinan Sirri Di Indonesia." Tabkim Jurnal Peradaban dan Hukum Islam) 1.2 (2018).
Sulaiman Jamal, Khasiyah Jamal 'alal Minhaj juz 3. Beirut: Dar al-Fikr, 2002.

Sulaiman al-Bujairimi, Khasiyah Bujairimi 'ala al Minhaj juz 4. Beirut: Dar al-Fikr, 2002.

Ash-Shiddiqiey, Hasbi. Falsafah Hukum Islam. cet.IV; Jakarta: Bulan Bintang, 1993.

Sururie, R. W. Polemik Di Seputar Hukum Isbat Nikah Dalam Sistem Hukum Perkawinan Indonesia. Al-Manabij: Jurnal Kajian Hukum Islam, 11(2), (2017).

Undang-Undang RI Nomor 1 Tahun 1974 tentang Perkawinan dan Kompilasi Hukum Islam, Dilengkapi : PP RI Nomor 9 Tahun 1974, PP RI Nomor 10 Tahun 1983, PP RI Nomor 45 Tahun 1990, Peraturan menteri Agama RI Nomor 11 Tahun 2007, Peraturan Menteri Pertahanan Keamanan/Panglima Angkatan Bersenjata

Nomor:Kep/01/1980, Petunjuk Teknis No. Pol.: JUKNIS/01/III/1981, Peraturan Kepala Kepolisian Negara RI Nomor 9 Tahun 2010, UU RI Nomor 41 Tahun 2004, UU RI Nomor 12 Tahun 2006, UU RI Nomor 23 Tahun 2001, PP RI Nomor 42 Tahun 
87 | Sabir, Aris, Iin, The Problems of the Khi..., pp. 68 - 87

2006, Keputusan Presiden RI Nomor 8 Tahun 2001, UU RI Nomor Tahun 2004. Surabaya : Sinarsindo Utama, 2015.

Zaidah, Yusna. "Isbat Nikah dalam Perspektif Kompilasi Hukum Islam Hubungannya dengan Kewenangan Peradilan

Yakin, Muhammad Khusnul. "Ratio Decidendi Penetapan Agama." Syariah: Jurnal Hukum Pengesahan (Itsbat) Nikah Di Pengadilan

Agama." Yuridika 30.2 (2015). dan Pemikiran 13.1 (2014). 